9

\title{
Rights, Pressures and Conservation in Forest Regions of Mexico
}

\author{
Leticia Merino
}

\section{Introduction}

The drivers of environmental degradation and the strategies to counter them are the subjects of heated debate. Several conceptual and policy approaches consider the key factors of this degradation to be the weakness and instability of property rights over natural resources. The commons perspective, on the other hand, emphasizes the viability and potential of the self-governance of shared resources such as forests. This perspective calls for a better understanding of the roles of local users and their institutions - understood as "rules in use" - with regard to natural resources (Ostrom, 1991; McKean, 2000; Berkes, 2006; McCay, 2007). In this literature, collective action is understood as cooperation and coordination to solve collective dilemmas related to the management of the commons (Cárdenas, 2008; Meinzen-Dick, 2010). The influence of the commons perspective goes beyond academia, gaining recognition among some international funders, environmental agencies and practitioners. It follows the repeated failures of previous efforts of international aid to halt deforestation through the support of governmental agencies.

This approach has led to two important policy proposals: (1) the decentralization of control over common resources to lower levels of government, including local user groups and stakeholders (Ribot, Agrawal and Larsson, 2006; Agrawal and Ashwini, 2009); and (2) the devolution of property rights to local users in order to create incentives and a commitment to sustainability (Whyte and Martin, 2003; Molnar and Alcorn, 2006; Barry, 2008). Although the "commons school" has had limited academic influence in Latin America, the region has been marked by proposals to decentralize forest governance and devolve 
rights to local communities. Such initiatives have been coherent with the struggles of local communities over land and natural resources all over the region. The "devolution" of forestlands to local populations has been an intense learning process, with a range of outcomes that need to be better documented and understood. This extends from the forest concessions to "comunitarios" in Petén Guatemala, the official recognition of traditional rights over the lands of the indigenous "mizquito" in Nicaragua, and the indigenous reserves in Panamá, Brazil and Bolivia; to the forest property of Afro-American communities in the Colombian Pacific and rubber tappers in Brazil. Experiences of collective action, local governance, rural development and conservation coexist with cases of conflict, elite capture and forest deterioration. "Community forestry" has been a positive option for conservation and local livelihoods in different regions. ${ }^{1}$ However, community-based governance is neither a panacea nor a reality to be taken for granted. The outcomes of these experiences derive from a variety of historical as well as recent factors, on which public policy often has major impacts.

Mexico stands as a singular case of community-based forest governance in Latin America. Mexican communities gained legal rights over lands and forests long before anywhere else in the contemporary world. At the same time, Mexico's deforestation rates were some of the highest in the world for decades (1970-1990). ${ }^{2}$ Forests cover more than $60 \%$ of the country, providing important ecosystemic services that benefit a range of actors. ${ }^{3}$ During most of the twentieth century, the forest industrial sector searched for access to low-cost raw materials. Backed by government agencies that promoted economic growth, their position weakened with the implementation of NAFTA. Since 1994 the Secretaria de Medio Ambiente Recursos Naturales y Pesca (SEMARNAP) has promoted conservationist measures that sought to minimize forest use in order to protect the megabiodiversity within, often drastically limiting human presence in forested and wild areas. ${ }^{4}$ Conservationist policies have gained influence in public opinion, backed by national and international environmental agencies. They tend to regard deforestation as a generalized process in the country, mainly driven by collective property regimes and rural poverty. Local communities are the legal owners of the majority of Mexico's forests. Although they were favoured by agrarian reform, they have rarely received coherent policy support to develop forest-based livelihoods and to become forest stewards. Most forest communities have weak political voices and exercise little influence on other social sectors. Community residents value and benefit directly from many of the forest's ecosystemic "services": goods for 
domestic consumption and the flow of goods harvested and processed for commercial purposes. For them, the forest has patrimonial value and represents a legacy to be passed down from their elders to their children.

The relationships between relevant stakeholders - including federal and state governments - are permeated by poor coordination, pronounced economic and political asymmetries, and misconceptions. Conservationists tend to dominate in the context of global concern over climate change and biodiversity loss. For international agencies and for the federal government, forests and climate-change policies are the fields of experts and the central government. They favour the recentralization of control over rural landscapes. Forest communities tend to be seen as obstacles to conservation and the mitigation of carbon emissions. Commoners' perceptions of environmental change, ${ }^{5}$ their increasing "climatic" vulnerability, their livelihoods and governance are mostly disregarded. The accomplishment of general mitigation targets is often prioritized over local adaptation needs.

Based on empirical research carried out in 103 forest communities, this chapter will discuss some of the main demographic and socioeconomic conditions of Mexico's forest communities, land-tenure features, forest use and local perceptions of pressures on forest areas. In addition, the relationship between local institutions, forest economies and social capital is analysed. Although the analysis focuses on Mexico, the experiences of community forest tenure and community forestry may provide useful insights into the general interaction of local communities with forests. This could be applicable to forest regions and forest policies in other Latin American countries.

\section{Forests in Mexico}

\section{Forest tenure and property rights}

Mexico has ecological, social and historical features that are similar to those of many Latin American countries. Much of the lands are forested and mountainous, and most forest areas are inhabited spaces. ${ }^{6}$ Forest regions are home to nearly 12 million people in Mexico, many of whom are indigenous and are living under conditions of extreme poverty (INEGI, 2010). Community property remained in place during the three centuries of the colonial rule (16th and 19th centuries) and continued to exist in areas where colonial control remained incomplete due to difficult access. During the nineteenth century, many communities lost their lands as privatization policies were imposed by the central government. Indigenous presence and collective property were regarded as 
backwards and saw privatization as imperative for economic modernity (see Chapter 1).

Despite these similarities, Mexico is a unique case in Latin America because powerful social movements brought about extensive landtenure reform when the state tried to resolve popular claims. The government's recognition of collective tenure as the basis for agrarian reform was guaranteed in the 1917 federal constitution. Today, 70\% of forestland is under collective tenure, while more than $50 \%$ of communities have forest cover (Warman, 2000; Bray and Merino, 2004; Merino, 2004; Bray, Merino and Barry, 2005).

Across the entire world, public property of forests (often under concessions to third parties) is the prevailing institutional arrangement. Only from the late 1980 s to the early 2000 s did communities and local groups obtain rights over forests in other Latin American countries, such as Nicaragua, Bolivia, Brazil, Guatemala, Peru and Colombia.

There are two legal types of collective holdings in Mexico: ejidos and comunidades agrarias. ${ }^{7}$ Ejidos were created when the government granted land to groups who demanded it, including former hacienda workers. Comunidades agrarias resulted from the official recognition of the historical rights of indigenous communities. CONAFOR estimates that today 30,305 communities collectively own 105 million Ha of forest. Legally, comunidades agrarias are able to incorporate young members at their will, while ejido members can only pass on their rights to a single successor. Community forests have to be commonly managed, and their division or sale is legally prohibited. ${ }^{8}$

In spite of the legal status of communities, their rights are clearly limited: the Mexican state maintains the right to regulate forest use. ${ }^{9}$ Second, as in most of Latin America, water and underground resources are legally public property, giving governments the right to directly use these resources or to grant them in concession to third parties. Finally, according to Mexican legislation, mining holds a national priority status over conservation and mitigation of global greenhouse gas emissions.

\section{Forest policies}

Since the late 1940s, industrial development based on an import substitution model became a national priority in Mexico. As in other large Latin American countries such as Brazil and Argentina, strong centralized governments assumed the role of directly promoting this model.

Small rural producers were given the role of providing staple foods at low cost, thereby enabling low industrial salaries. ${ }^{10}$ The state did not 
consider members of forest communities to be capable of managing forest operations. Instead, long-term concessions of community forests were imposed in different regions in order to give industries access to raw materials. Similarly, communities lost their rights in almost half of the forestland where logging bans were imposed to protect river basins. From the perspective of some commoners, these policies made forests an obstacle to real ownership of the land. Confronted by continuous local resistance, forest industries were organized for short-term profits and they kept their rate of reinvestment as low as possible. In the 1970s, forest industries were nationalized. The Mexican state used the profits of forest exploitation for investments in other economic sectors. Forest regions under logging bans suffered strong deterioration as private forest industries continued their operation in those areas. Logging activities were carried out without any restrictions or provisional measures (Bray and Merino, 2004; Merino, 2004; Boyer, 2005; Merino and Segura-Warnholtz, 2005; Bautista, 2007). ${ }^{11}$

In the 1970s this economic and political model started to show signs of exhaustion. With regard to forest policies, neither concessions nor logging bans accomplished their economic or environmental goals. Forest deterioration increased while most industrial logging plants operated below their installed capacity. ${ }^{12}$ Concessions favoured "rent extraction" over sustained exploitation, reinvestment in forest protection and long-term management systems. This led to a "disinvestment" and consequently resulted in the loss of forest resources, value and productivity.

By the early 1980s, when the concessions were close to expiring, many communities claimed the right to regain the use and control of their forests. Social mobilization, support of civil society groups and the closing of many state-owned industries enabled communities in Mexico to win this struggle. After having worked for concessionaries for many years, community members realized that timber extraction could be profitable and sustainable. Some communities engaged in community forest production. Their initiatives were supported by a progressive group within the federal administration: the Dirección de Desarrollo Forestal (DDF), which held the view that communities could be both efficient producers and forest stewards. The DDF promoted the organization of community unions to create economies of scale that would enable communities to hire technical advisors who were previously provided by the federal government. Through these unions, communities gained a stronger presence both in politics and in the market (Alatorre, 2000; Bray and Merino, 2004; Chapela, 2005). In 1986 a new forest law 
banned concessions and granted communities the right to be consulted on the implementation of any policy that restrained their property rights.

Communities with the most valuable forest assets and good organization showed remarkable achievements. They reinvested most of their profits from forest businesses in improved forest-management systems, building and providing for the maintenance of forest roads. They also acquired industrial equipment, and organized their own technical and administrative teams. Not only did forestry provide employment and income to local residents but its profits were invested in local public goods: schools, clinics, community celebrations, roads and transport. Some communities adopted environmental agendas to promote sustainable harvests, minimize environmental impacts and diversify forest use. Since the 1990s a group of communities were granted forest certification under the Forest Stewardship Council scheme. There are currently 39 certified community forests in Mexico, amounting to $655,206 \mathrm{Ha}^{13}$

These successful forms of community forest management created local incentives for conservation, improved quality of life in marginalized regions, and favoured democratic governance of forest commons. Some certified communities have even gained international recognition. ${ }^{14}$ The experience of the ejidos of southern Quintana Roo was replicated in the neighbouring tropical forests of Petén-Guatemala, where Mexicans trained local user groups and thus supported the establishment of community forestry operations.

Sustainable forest management and production - one of the strategies proposed to halt deforestation - require coherent and continuous long-term support to local users. However, government support for community forestry faded during the late 1980s and early 1990s. With the implementation of NAFTA, the national market was abruptly opened and community producers were unable to compete with US and Canadian forest producers. At the same time, the over-regulation of forest activities by the Mexican state led to high transaction costs. Finally, subsidies for tropical agricultural, cattle holding ${ }^{15}$ and the extension of illegal logging led to the disruption of some community forestry initiatives during that period. ${ }^{16}$ NAFTA therefore put pressure on the productive initiatives of forest communities. While some exportoriented subsectors in agriculture, manufacturing and services benefited, many small and medium-sized (urban and rural) businesses failed in the absence of policies to protect and promote their productivity and competitiveness. 
In 1994 the federal administration created the Ministry of the Environment, SEMARNAP, with forest management as part of its jurisdiction. SEMARNAP's main natural resources policy was the expansion of the protected areas system and a simultaneous increase in regulations for activities such as forestry. Nevertheless, SEMARNAP also renewed support for community forestry, creating two small programmes: PRODEFOR (Programa para el Desarrollo Forestal) and PROCYMAF (Programa de Conservación y Manejo Forestal), a joint initiative of SEMARNAP and the World Bank. PROCYMAF was a pilot project based on the recognition of a variety of socioeconomic and ecological conditions of forest communities, and on the need to continue to build finetuned strategies to address the diversity of local contexts. ${ }^{17}$ PROCYMAF was influenced by the international advocacy in favour of participatory, decentralized, pro-poor forest policies that emerged during the 1990s and 2000s. Its main goals were to strengthen communities' social capital, and their productive and institutional capacities. After a few years, PROCYMAF presented some important achievements, such as a growing system of forest area under certification, the creation of numerous community forest enterprises, the adoption of participatory land-use planning, the definition of community rules for local forest governance, and the establishment of regional committees of forest communities.

After the Partido Acción Nacional (PAN) took over the national government in 2000, Mexico's economy and governability were increasingly characterized by corruption and authoritarian practices. Aiming to increase its legitimacy and to show political strength, the PAN government launched an extensive "anti-drug war". In the context of economic and institutional failures, widespread corruption, persistent poverty and inequality, this led to the spread of violence to many regions. Criminality against the population became common, involving criminal gangs but also the police and the army (Cendejas, 2015).

At the same time the PAN administrations (2000-2012) responded to environmental concerns that tried to give forest policy a high profile. Between 2000 and 2008, public investment in forests increased by $7000 \%$ (Figure 9.1). The distribution of these public funds expressed a conventional conservationist vision. About $70 \%$ was invested in the establishment of forest plantations and massive reforestation programmes. In general, these investments yielded poor results. ${ }^{18}$ Some $12 \%$ of the funds were used for the Programme of "Payment for Environmental Services" (PES), and were given to forest owners who gave up forest use. ${ }^{19}$ Only $10 \%$ of the federal forest budget was used to support community forestry (Merino and Ortiz, 2013). 


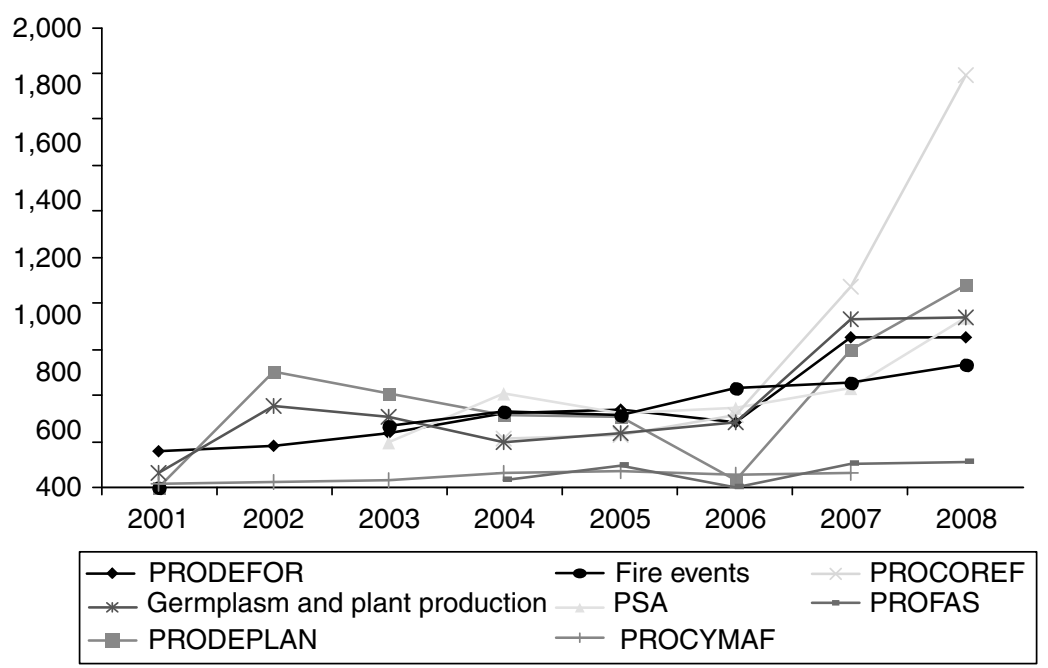

Figure 9.1 National annual budget of CONAFOR according to different forestrelated projects in Mexico (in million pesos), 2001-2008 Source: Merino and Ortiz (2013).

\section{Forest communities in Mexico}

Forest communities in Mexico exist in a range of socioenvironmental contexts. This study is based on an analysis of a sample of 102 forest communities, which basically tested two main hypotheses (following Cárdenas, 2006):

- forest conditions and sustainable forest use depend largely on the robustness of local institutions; ${ }^{20}$

- institutional robustness relies on interlinked characteristics of forest users, namely, social capital and dependence on forest resources. ${ }^{21}$

The sampled communities are distributed across five states: (1) Oaxaca in the south, where 19 indigenous groups (mainly Zapotecos and Mixtecos) constitute the majority of the population; (2) Guerrero, also in the south, with an important presence of Nahuas and Mixtecos; (3) Michoacán in central Mexico, home of the Purépechas; (4) Jalisco in the west, whose mountains are home to the Huichol people; and (5) Durango in the north-centre, with five indigenous groups, mainly Tepehuanes. ${ }^{22}$ Together these states add up to more than half of the forestland of 
Mexico, where approximately $70 \%$ of the nationally produced timber comes from. As a whole, these forest regions have a lower population density and lower deforestation rates than the rest of the temperate forest areas. ${ }^{23}$ The remainder of this chapter will provide a detailed analysis of forest conditions, use and governance in the studied areas.

\section{Forest types and uses}

The sampled communities are located in the mountain range along the Pacific coast and the central neovolcanic axis, at high altitudes. These areas frequently have important altitudinal ranges of non-forested lands and different types of forest vegetation, including temperate forests (pine, pine-oak, oak, fir and cloud forests), as well as dry and humid tropical forests (below 1,500 to $500 \mathrm{~m}$ above sea level. Distinct types of forest are perceived, used and managed in different ways.

Forest uses vary according to forest type (Table 9.1). Firewood is the only type of wood collected in almost all type of forest. Commercial logging - the most important income-generating forest activity - takes place in about half of the pine and pine-oak community forest areas. Agriculture and grazing - sometimes based on the removal of the forest cover - take place in the dry and tropical forests. Interestingly, community conservation initiatives, sometimes supported by government programmes, are not present in tropical humid and tropical dry forests within the sample. The latter type of forest has the greatest biodiversity and number of endemic species, and it represents the most endangered forest type in Mexico. ${ }^{24}$

In summary, sustainable use options are limited or absent in most of the community forests analysed in this study. The lack of these

Table 9.1 Different uses of forest by community residents in Mexico

\begin{tabular}{lccccc}
\hline Type of forest & $\begin{array}{l}\text { Firewood } \\
\text { collection } \\
\%\end{array}$ & $\begin{array}{l}\text { Grazing } \\
\%\end{array}$ & $\begin{array}{l}\text { Agriculture } \\
\%\end{array}$ & $\begin{array}{l}\text { Conservation/ } \\
\text { PES \% }\end{array}$ & $\begin{array}{l}\text { Logging } \\
\%\end{array}$ \\
\hline Pine & $65^{25}$ & 60 & & 62 & 58 \\
Pine-oak & 81 & 60 & & 18 & 48 \\
Oak & 92 & & 30 & 70 & \\
Fir & 45 & & & 80 & \\
Cloud & & & & & \\
Tropical dry & 41 & 75 & & & \\
Tropical humid & 61 & 75 & & & \\
\hline
\end{tabular}

Source: Survey on Forest Communities with Temperate Forests in Mexico, IIS-UNAM. 
opportunities endows forests with low social value. Under such conditions, forest areas are prone to highly impactful activities, such as mining or commercial plantations. ${ }^{27}$

\section{Forest size and tenure issues}

Forest resources are valuable assets for the majority of the communities, particularly those that own forest resources of commercial value. ${ }^{28}$ In most cases, however, forest areas are relatively small. Only $10 \%$ of the communities have more than 10,000 $\mathrm{Ha}$, while half of them are smaller than $2,000 \mathrm{Ha}$ and $20 \%$ of communities possess forests of between 500 and $300 \mathrm{Ha}$.

The governance of communal forests has the potential to generate a range of social benefits, including more participation in forest protection (Merino, 2005; Agrawall and Ashwini, 2009). However, collective tenure does not necessarily lead to equal access to forest resources for all community members, or to equal incentives to protect them. The two types of communal forest in Mexico - ejidos and comunidades agrarias - present important differences. In ejidos, which are predominant in Durango, Jalisco and Michoacán, many families do not have property rights, while comunidades agrarias own $95 \%$ of the forests in Oaxaca. Ejidos also face serious ageing problems $-88 \%$ of the rights holders are at least 40 years old and $28 \%$ are over 60 years old. In contrast, $64 \%$ of the residents in comunidades agrarias are younger than 40 . The different age structure results from the legal rights of comunidades agrarias, which facilitate the inclusion of new members.

Collective tenure in Mexico remains strong in spite of the many pressures that it faced before and after the 1991 legal reform that enabled the privatization of ejido lands (Wayne, 1998; Warman, 2000). Sales of ejido lands occurred in $30 \%$ of the sampled communities. ${ }^{29}$ In $82 \%$ of the communities, local authorities declared that the majority of community members favour the maintenance of collective property.

Conflicts over land tenure are not rare in the case studies. In particular, intercommunity conflicts over borders occur in $34 \%$ of the cases. Intracommunity conflicts over the limits of individual plots were reported in $21 \%$ of the studied communities. Conflicts over borders are more frequent in comunidades agrarias, where these problems have remained unresolved for generations. Such conflicts usually have negative impacts on forest conditions due to unclear ownership. According to local authorities, they favour deforestation and illegal logging, and therefore create challenges for implementing protective measures. 


\section{Forest Communities performance}

The performance of forest communities was measured by five indices: (1) pressure on forest areas; (2) protection and conservation activities; (3) social capital and organization; (4) local institutional strength; and (5) community forest economy ${ }^{30}$. Table 9.2 summarizes the main results, divided into five rank categories.

Table 9.2 Indices of forest communities' performance

\begin{tabular}{lccccc}
\hline Index & Very low \% & Low \% & Moderate \% & High \% & $\begin{array}{c}\text { Very } \\
\text { high \% }\end{array}$ \\
\hline $\begin{array}{l}\text { Pressure on forest } \\
\text { areas }\end{array}$ & 10.7 & 26.2 & 26.2 & 12.6 & 24.3 \\
$\begin{array}{c}\text { Protection/ } \\
\text { conservation }\end{array}$ & 35.9 & 27.2 & 22.3 & 9.7 & 4.9 \\
$\begin{array}{c}\text { activities } \\
\begin{array}{c}\text { Social capital and } \\
\text { organization }\end{array}\end{array}$ & 3.9 & 23.3 & 53.4 & 16.5 & 1 \\
$\begin{array}{c}\text { Local institutional } \\
\text { strength }\end{array}$ & 27 & 27 & 36 & 10 & 0 \\
$\begin{array}{c}\text { Community forest } \\
\text { economy }\end{array}$ & 69 & 13.6 & 7.8 & 5.4 & 3.9 \\
\hline
\end{tabular}

$\mathrm{N}=103$.

Source: Survey on Forest Communities in Mexico, IIS-UNAM.

The pressures on forest areas index combines (1) occurrence of illegal logging; (2) forest fires and pests; (3) grazing in forest areas; and (4) land-use change. The results show that pressures on forest areas are remarkable in nearly $37 \%$ of the sampled communities, while a very similar proportion of the community forests face low levels of pressure. It is worth mentioning that questions have arisen during the past decade about the perception of change (increase or decrease) in forest pressures. Most of these pressures have a socioecological basis. In particular, effects of global change add a level of uncertainty regarding the occurrence of fires and pest outbreaks, as well as in rainfall and drought patterns. A significant share of these communities (16.5\%) reported recent forest losses.

The conservation and protection activities index combines variables related to (1) monitoring of forest areas in order to address forest fires, pests and illegal logging; (2) local organizational and technical capacities to face these pressures; (3) initiatives of reforestation; and (4) the 
existence of community conservation areas. This index was built to capture practices that favour conservation rather than actual conservation or degradation of forest areas. ${ }^{31}$ Protection and conservation practices are low in the majority of the cases (63\%). However, in $27 \%$ of the communities where conservation and protection activities were ranked as "low", communities perform basic protection activities such as fire-fighting. It is interesting to note that the proportion of communities with very poor conservation practices is similar to the percentage of communities where forest pressures are perceived as "high" and "very high". In communities where conservation and protection measures are moderate $(22.3 \%)$, residents are engaged in the monitoring of forest areas.

Only in $14.6 \%$ of these communities were conservation and protection practices classified as "high" and "very high". A relevant finding is the presence of community conservation areas, particularly in the comunidades agrarias with indigenous background (61\% of the sampled communities in Oaxaca, and 58\% in Guerrero). Community conservation is also significant in $44 \%$ of the ejidos and comunidades agrarias in Michoacán, and among 38\% of the ejidos in Durango. Many of these conservation areas are located in areas identified as water-capture sites and have been established as part of community projects to protect water sources.

The social capital and organization index includes (1) frequency of community meetings; (2) strength of local governance systems; (3) participation in community meetings; and (4) non-paid community work. This index is particularly important as social capital and organization are considered by the "commons school" to be preconditions for forest governance and sustainability (Ostrom, 2009). Social organization in ejidos and comunidades agrarias faces a variety of challenges and has important downsides: the exclusion of women and young people; conflicts created by the "elite capture" of benefits of common resources; and the "costs" of traditional practices of governance and reciprocity. Increasing outmigration puts social organization under additional stress, as it drains crucial human resources needed for local governance and generational replacement. This adds to the challenge of maintaining social capital across different generations. These pressures are particularly strong in about one-quarter of the sampled communities (27.2\%), where the value of this index is "low" and "very low".

Governance based on local participation takes place through regular community assemblies to discuss collective issues, make decisions and formulate rules about the following issues: use and management of the 
forest commons, use of the profits of the communal productive initiatives, and relationships with government programmes. Community members take part in different positions of the local governance system, mostly on a voluntary basis. In addition, non-paid community work which takes place in many cases - serves as a base on which to build and maintain collective infrastructure, public services, forest protection and forest-restoration activities.

Despite the organizational foundation observed in many forest communities, the low percentage of communities with a higher level of organization and social capital (17.5\%) reflects the high costs of community and common forest governance. Within this sample, lower values of social capital and organization are often linked with the exclusion of avecindados (family heads living in communities), lack of property rights and little or no rights to take part in meetings or use common resources.

The local institutional strength index is based on (1) the existence of community rules for local governance; (2) rules related to the use and provision for local commons (e.g. public spaces, forests, infrastructure, community profits from forestry or other collectively held activities); (3) community participation in the definition of the agreement; (4) awareness and knowledge; (5) monitoring and sanctioning of compliance with the rules; and (6) community members' trust in rule compliance. Local institutions are considered fundamental for sustainability and governance by the "commons/collective action perspective" as they are the result of collective agreements for commons governance and use. Nevertheless, the definition and enforcement of local institutions are demanding tasks. Community participation and knowledge are required to legitimate local rules and better match the local context. Communities of users and/or owners of common resources coordinate to create collective institutions when they perceive the need and have the conditions that enable them to do so.

In most of the communities under study, local rules refer to local governance and, sometimes, to the extraction and use of firewood. The values of this index express a relative weakness of local institutions: a lower level in half of the communities' local institutions and high in only $10 \%$ of these communities (Table 9.2).

This pattern partially reflects the centralized forest governance in Mexico, in which local communities are completely excluded from the definition of use and management rules. As a result, national rules are often inadequate for particular forests or communities in a large and highly diverse country. In addition, frequent changes in laws and 
rules increase uncertainty and the ability of forest users to comply with government regulations.

Conflicts between local and national monitoring systems add to the challenges for local institutions. In Mexico a federal government agency (the Procuraduría de Protección Ambiental) is officially responsible for monitoring compliance with federal forest rules. Limited coordination between the Mexican environmental enforcement agency (PROFEPA) and the monitoring initiatives of local communities leads to conflict between the two institutional arrangements. Imposed rules, external and often inefficient - monitoring and sanctioning, "crowd out" risk, and eroded local institutions have resulted in a favouring of local "open access" conditions (Cárdenas, 2008).

Finally, the community forest economy index combines (1) a level of vertical integration of forest production and the capacity to add value to forest products; (2) diversification of forest uses, taking commercial and domestic purposes into account; (3) productive forest assets owned by communities; and (4) ownership of financial assets. This index corresponds to "forest dependence", an important condition for the social value of common forests, and the incentives to commit to their governance and conservation (Ostrom, 2009).

The level of development of the communal forest economy was considered "very low" in $69 \%$ of the sampled communities. In half of the communities, forest only provides firewood for domestic use. In the other half, residents harvest and sell non-timber forest products (NTFP) such as mushrooms, resin, medicinal plants and firewood. ${ }^{32}$ Individuals or family groups who take part in these activities are often the poorest members of the community. These products deliver very low profits due to market control by intermediaries.

Logging remains the most important (legal) income-generating activity in forest regions. It takes place in one-third of these communities, of which $13.6 \%$ sell timber as "stump". In these cases, outsiders perform forest management and extractions with little community control. These operations, which often have a high impact on forests, deliver scarce local benefits, and create mistrust and opposition to commercial forestry.

Forest management and timber-harvesting operations are carried out in only $17 \%$ of the communities. About half of this last subgroup produced only raw material (logs) due to limited productive capacities and financial resources to cover production costs. Nearly $10 \%$ of these communities have achieved productive vertical integration, including their own forest mills and sale of primarily tables. However, only $4 \%$ of the 
sampled communities have achieved vertical and horizontal integration as forest producers. They have diversified commercial forest uses, combining timber products with NTFP and/or providing ecotourism services. This low performance reveals the challenges faced by the community forestry industry - namely, the organization of production, how to reach national and international markets, financial and fiscal tasks, efficiency, accountability to communities' assemblies, and the operation of entrepreneurial administrations in the context of local governance systems. Nevertheless, these communities have created local sources of employment and income. They have financed local infrastructure and public services with the profits of their own business. They have also contributed to developing and strengthening human resources, social capital and local governance (Bray, 2007). The following section shows how the community forestry economy is related to forests and communities.

\section{Forest communities and community forestry}

Community forestry touches upon the socioeconomic conditions of the community as well as ecological conditions and pressures of the forest. The indexes analysed in the previous section reveal that social organization, forest conditions and forestry are closely related. ${ }^{33}$

Organization around local governance, and commons management and use, is present in many forest communities. However, communities with weak local institutions tend to report a higher level of pressures in their forests. Conflict over community borders is particularly related to increasing pressures on forest areas, which are almost four times as greater as for communities that do not face this problem. In contrast, communities that control forest management and forest production tend to be more involved in protection and conservation activities. Furthermore, communities with internal rules regarding the protection and management of forests tend to be more successful in addressing pressures on forests. Their members engage in the reduction of the risks of forest pests and fires. They also monitor forest areas in order to observe early signs of potential threats. Nevertheless, the level of pressure varies considerably according to the individual forest dynamics. Fires and pests, for example, are multifactorial, in which climatic events such as strong and/or longer dry seasons may play an important role. Therefore, as pressures on forests increase, local rules must be fine-tuned as well.

Not surprisingly, we found a strong relationship among social capital and organization and local institutional strength. Basic organizational 
practices, such as collective rules in use and trust, are important for promoting social capital. In general terms, communities with the strongest organization are also those where protection and conservation activities are more frequent and diverse. This pattern reveals the relevance high levels of social organization required to support local coordination and collective action addressing forest protection and conservation activities. A small number of communities, however, perform forest-protection activities at high intensity. This pattern is a possible outcome of government subsidies for reforestation. In contrast, a reduced number of highly organized communities showed very few protection and conservation practices. These cases reveal that communities may be organized for different purposes that do not necessarily coincide with forest conservation. In summary, social organization is an important requirement for performing conservation activities but it is not sufficient for creating incentives to engage in forest protection.

Protection and conservation activities are closely related to the development of community forestry. The forest economy tends to be low where local institutions are weak. As a result, limited protection and conservation activities lead to increased pressure on forests. Interestingly, pressure on forests drops considerably according to the increasing importance of commercial forest activity in communities. In cases where recent deforestation took place, forest economy in the communities is weak. In general, communities with lower levels of pressure on forests are those with the most consolidated economic forest activities. This information suggests that as the incentives, knowledge and technical skills increase - as a result of a more diversified community forest economy - community members are more able and willing to identify and address pressures on forests before their impacts grow out of control.

Communities with the highest level of local forest economy ${ }^{34}$ tend to have lower institutional strength in comparison to communities with only vertical integration of forest production. The former needs stronger and more diversified institutions in order to manage industrial and commercial operations, diversify forest production and carry out multiple activities, such as timber extraction and processing. However, as these data reveal, new economic forest activities may lack the institutional support to scale up their commercial activities. If not properly addressed, these "institutional gaps" can undermine common natural resources used in production processes, collective initiatives and community governance itself. 


\section{Conclusion: Community forestry beyond autonomy}

In highly unequal societies such as those in Mexico and most of Latin American countries, governments and urban societies need to overcome the anti-rural, anti-community, anti-poor biases that are frequent in legal frameworks, and in environmental and economic policies. For decades, Mexican forest communities have faced adverse policies that constrain local initiatives. These have encouraged the abandonment of many forest and rural regions where local livelihoods have become difficult to sustain. Research on local forest use in Mexico and other developing countries (IFRI; Ribot, Agrawal and Larsson, 2009) shows a permanent tension between trends of decentralization and centralization of decision-making rights over natural and strategic resources.

Most Latin American forests are owned by central governments while logging concessions are given to international corporations (Whyte and Martin, 2001). Concessionaires tend to maximize short-term profits of forest operations to reinvest outside the country. As a result, forests become sources of revenue for national governments with limited local control over the impact of extractions.

Not surprisingly, this model of "mining forestry" leads to the marginalization of local people and high environmental impacts. The last two federal administrations in Mexico (2000-2012) responded to global environmental concerns, thereby attempting to give forest policy a high profile. Despite the increased public investment in forests between 2000 and 2008, this budget largely overlooked the needs to promote local productive and governance capacities, and the creation of stable incentives for conservation.

Successful experiences of community forestry have revealed important lessons that can change this trend. They reveal positive synergies not only among common forest management, local livelihoods and conservation but also with maintenance and the development of "commonality" based on local institutions and social capital. The results of this research show that social capital and institutional strength are key factors for the protection of forest commons, and for local capacities to face traditional and emergent pressures on forest ecosystems. Human resources and collective action are critical for resilience. The presence of communities with forest conservation, governance and local development in Mexico shows the viability of these initiatives, even if they still constitute a minority.

Forests are commons whose sustained management and use require high levels of cooperation among relevant actors. Collective action in Mexican communities is even more necessary due to the collective 
tenure of the vast majority of Mexican forests. Communal property can be an important possibility for favouring sustainability and the governance of complex ecosystems, such as forests. However, despite the relevance of legal recognition of property rights over lands and forests to local communities, it is hardly sufficient for forest communities to achieve their economic, environmental and social potential. The empowerment of local communities by acquiring technical and governance capacities is equally important in contemporary contexts. The results of this survey show the existence of many communities that suffer forest deterioration and limited social capital. In these communities, the contribution of forest activities to local livelihoods is often very limited. The development of a forestry economy is fundamental not only for supporting the social and institutional development of these communities but also for delivering protective measures for sustainable forest use.

The experience of forest communities in Mexico shows that the synergy between forest economy and conservation does not happen naturally; it requires favourable public policies as well as access to adequate training and technical advice.

The state has undermined community rights and livelihoods, favouring communities' dispossession. This entails a recentralization of land control and resource management, over-regulation of resource use, imposition of high transaction costs on legal forest use, and criminalization of many local uses of natural resources. But if local governance and environmental citizenship are regarded as assets for conservation and governability, the state can play a key role by recognizing communities' rights over natural resources. This would provide favourable legal frameworks for community forest use and governance - by coordinating with local actors to control illegal land use - and would favour markets able to internalize sustainable management costs.

Lessons from Mexico's community forestry experience are relevant for other Latin American countries, such as Guatemala, Nicaragua, Bolivia and Brazil - where governments recognize local collective rights. In countries where most of the forestlands are owned by governments and are used by private companies, local governance, incentives and recognition of communities' rights can be avenues for reversing environmental injustice and deterioration. In summary, community forestry is not a panacea or a fixed model that can simply be replicated inside or outside Mexico. Nevertheless, it represents an important alternative to combine goals of local empowerment, forest sustainability and rural development. While some communities in Mexico seek to distance themselves from the state and the traditional market (see 
Chapter 10), other communities may find their sustainable development path through close support from the state and market integration.

\section{Notes}

1. I consider "community forestry" to be those cases in which local communities have and practise use and control rights over the forested areas (Schlager and Ostrom, 1992) and where they preserve the forest cover and have instituted use and management rules, regardless of the ways in which they use forest resources.

2. About $3 \%$ yearly.

3. The Millennium Ecosystem Assessment defines these "services" as provisional, regulatory, cultural and support services.

4. Mexico has the fifth greatest biodiversity in the world; the top ten megadiverse countries host 70\% of the Earth's biological diversity.

5. The Stockholm Resilience Center defines interrelated dimensions of global environmental change as loss of biodiversity, ocean acidification, changes in the cycles of phosphorus and nitrogen, land-use change, depletion of the atmospheric ozone layer, pollution of soils and water, and aerosol atmospheric load (Rockstrom et al., 2009).

6. Some $73 \%$ of the land has forest cover, accounting for nearly 142 million Ha.

7. I use the term "community" when referring to both ejidos and comunidades agrarias.

8. De facto forest division is happening in many communities.

9. In terms of the "bundle of property rights" scheme proposed by Schlager and Ostrom (1992), community members have access, use, exclusion and some management rights over forests. The federal government maintains key control rights over them.

10. The Mexican diet was based on corn and beans, the prices of which were controlled by the federal government for decades.

11. From 1950 to 1970 the national demand for forest products grew continuously and the country's economy grew by 7\% annually. From 1950 to 1989 , the population growth rates were close to $3 \%$ per year. These were also years of strong expansion of the market economy in traditional rural communities.

12. Communities with forests under concessions were not legally able to use them, nor were they free to choose timber buyers or negotiate timber prices, which were fixed by the Ministry of Agrarian Affairs. Nevertheless, they kept the right to allow or refuse logging in their lands.

13. During the last decade, certified forest areas have decreased as certification poses strong demands without giving clear access to better marketing conditions.

14. San Juan Nuevo in Michocán; Ixtlán, UZACHI, Ixtlán, Textitlán, Mancomunados and San Pedro el Alto in Oaxaca; Santiago Papasquiaro in Durango; el Balcón in Guerrero; el Largo in Chihuahua; Nohbec in Quintana Roo. 
15. Some subsidies for small agriculture were created after the implementation of NAFTA, mainly with political purposes. This is the case for PROCAMPO, which provided resources per hectare planted with corn, regardless of its productivity. Subsidies to acquire cattle were maintained until recently, given mainly by state governments.

16. It has been estimated that illegal logging is at least as great as legal production (Consejo Civil Mexicano para la Silvicultura Sostenible - CCMSS, PROFEPA).

17. PROCYMAF worked in the states of Oaxaca, Guerrero, Michoacán, Jalisco, Quintana Roo and Durango.

18. By 2009, Greenpeace reported that official reforestation had a survival rate close to $10 \%$.

19. Payments were established based on the average price of corn at an estimated national agricultural productivity average in areas with no irrigation.

20. Institutions are defined as "rules in use" (Ostrom, 2005).

21. This study was carried out as part of the international programme Forest Resources and Institutions (IFRI). A global database of forests and forest users around the world has been developed since the 1990s (Wollenberg et al., 2007). By focusing on two hypotheses of the IFRI programme (Cárdenas, 2006), a team from the Instituto de Investigaciones Sociales of the National University of Mexico (IIS-UNAM) applied a survey inspired by the IFRI conceptual approach.

22. The universe of the sample includes all the communities in these five states with at least $300 \mathrm{Ha}$ of temperate forest. It is stratified based on the proportion of communities with this characteristic in each state, as compared to the total number of communities with $300 \mathrm{Ha}$ (or more) of temperate forest in these five states.

23. The results of the survey are representative of half of Mexican temperate forests that face less pressure. We could not include the state of Chihuahua (the second largest timber producer in Mexico, which has the largest forest extension and where the conditions of forest regions are similar to those of the state of Durango).

24. Mexico's dry forests are rich in "neo-endemism" (new species that originated in a particular region and are only found there). This is currently the fastest-disappearing forest type. Mexican cloud forests are rich in "paleoendemism".

25. This is the percentage of forests of each of type within the communities of the sample.

26. During 1970-1980, subsidies for sun coffee based on the removal of the forest were the main driver of the rapid disappearance of cloud forests; since 1990, many communities have grown shade coffee, preserving forests. Some of them are certified as organic sustainable coffee producers.

27. From 2006 to 2012 the areas subject to mining concessions in mountain forests increased by 30\%. Much of the medium- and small-scale mining is now controlled by drug cartels, as in the southern sierra of Michoacán, which is rich in iron ore deposits. Other activities with a high environmental impact that are practised in dry forests include the establishment of plantations (e.g. Agave cupreata, used for the fabrication of tequila), illegal cropping and extensive cattle ranching. 
28. Mainly pine.

29. These are primarily sales of plots among ejido dwellers. In most cases, they are not associated with privatization of the ejidos. They do not include sales of forestland.

30. See methodology used for the construction of these indices at the site http://www.ccmss.org.mx/documentacion/830-a-vuelo-de-pajarolas-condiciones-de-las-comunidades-con-bosques-templados-en-mexico-borr ador/

31. The assessment of forest conditions requires other types of research methodology and techniques.

32. These are wood products classified as NTFP.

33. For a more detailed description of these data, see Merino, Leticia and Martínez Ana Eugenia, "A vuelo de pájaro. Las condiciones de las comunidades con bosques templados en México", www.conabio.gob.mx.

34. Industrial capacities, diversification of forest production: NTFP, environmental and touristic services and so on.

\section{References}

Agrawal, A. and Ashwini, C. (2009) 'Trade-Offs and Synergies Between Carbon Storage and Livelihood Benefits from Forest Commons', Proceedings of the National Academy of Science 106(42), 17667-17670.

Alatorre, G. (2000) La Construcción de una Cultura Gerencial Democrática en las Empresas Forestales Comunitarias (México, D.F: Editorial Juan Pablos, Procuraduría Agraria).

Bautista, L. (2000) Las Vedas Forestales en México. Tesis de Maestría en Estudios Regionales (México: Instituto Dr. José María Luis Mora).

Bevir, M. (2013) Governance: A Very Short Introduction (Oxford, UK: Oxford University Press).

Boyer, C. (2005) 'Contested Terrain: Forestry Regimes and Community Responses in Northeastern Michoacán, 1940-2000', in D. Bray, L. Merino and D. Barry (eds), The Community Forests of Mexico: Managing for Sustainable Landscapes (Austin: University of Texas Press), 27-48.

Bray, D. and Merino, L. (2004) La Experiencia de las Comunidades Forestales Mexicanas (México: Instituto Nacional de Ecología).

Bray, D., Merino, L. and Barry, D. (eds) (2005) The Community Forests of Mexico: Managing for Sustainable Landscapes (Austin: University of Texas Press).

Cárdenas Campo, J.C. (2009) Dilemas de lo Colectivo: Instituciones, Pobreza y Cooperación en el Manejo Local de los Recursos de Uso Común (Bogotá: Universidad de los Andes, Facultad de Economía, CEDE, Ediciones Uniandes).

Chapela, F. (2005) 'Indigenous Community Forest Management in Sierra de Juánez', in D. Bray; L. Merino and D. Barry (eds), The Community Forests of Mexico: Managing for Sustainable Landscapes (Austin: University of Texas Press), 91-110.

Durán, E., Mas, J. and Velásquez, A. (2005) 'Changes in Land Vegetation Cover and Land Use Change in Communities with Forest Management and Protected Areas', in D. Bray, L. Merino and D. Barry (eds), The Community Forests of Mexico: Managing for Sustainable Landscapes (Austin: University of Texas Press). 
De Janvry, A., Salouet, E. and Gordillo, G. (1999) La Segunda Reforma Agraria de México: Respuestas de Familias y Comunidades 1990-1994 (México: El Colegio de México).

Demzets, H. (2002) 'Towards a Theory of Property Rights II: The Competition Between Private and Collective Property', The Journal of Legal STudies 31(2):653-672.

Hardin, G. (1968) 'The Tragedy of the Commons', Science 162(3859): 1243-1248.

INEGI (2010) Censo General de Población y Vivienda (Instituto Nacional de Geografía y Estadística).

Larson, A., Cronkleton, P., Barry, D. and Pacheco P. (2008) Tenure Rights and Beyond: Community Access to Forest Resources in Latin America. Occasional Paper no. 50 (Bogor, Indonesia: CIFOR).

Manson, R. and Jardel, E. (2012) 'Perturbaciones y Desastres Naturales: Impactos sobre las Eco-Regiones, la Biodiversidad y el Bienestar Socioeconómico', in Capital Natural de México, vol. II: Estado de Conservación y Tendencias de Cambio (México: CONABIO), 131-184.

McCay, B.J. (2007) 'Introduction to Human Ecology. On Marine Resources', Human Ecology 35(5): 513-514.

McKean, M. (2000) People and Forests: Communities, Institutions, and Governance (Cambridge: MIT Press).

Meinzen-Dick, R. (2007) Proceedings of the National Academy of Sciences 104(39): 15200-15205.

Merino, L. (2004) Conservación o Deterioro. El Impacto de las Políticas Públicas en las Comunidades y en los Bosques de México (México: Instituto Nacional de Ecología).

Merino, L. (2010) Interview with Elinor Ostrom. The Commons Digest (also in youtube), www.iasc-commons.org, date accessed 12 January 2015.

Merino, L. and Martínez, A.E. A Vuelo de Pájaro. Las Condiciones de las Comunidades con Bosques Templados en México. www.conabio.org.mx, date accessed 22 January 2015.

Merino, L. and Ortiz, G. (2013) Encuentros y Desencuentros: Las Comunidades Forestales y las Políticas Públicas en Tiempos de Transición (Mexico: Miguel Angel Porrua/ Instituto de Investigaciones Sociales de la UNAM).

Merino, L. and Segura-Warnholtz (2005) 'Forest and Conservation Policies. Impacts on Forests Communities in Mexico', in D. Bray; L. Merino and D. Barry (eds), The Community Forests of Mexico: Managing for Sustainable Landscapes (Austin: University of Texas Press), 49-70.

Molnar, A., Scherr, S. and Khare, A. (2004) Who Conserves the World's Forests. A New Assessment of Conservation and Investment Trends (Washington, DC: Forest Trends).

Millennium Ecosystem Assessment (2003) Ecosystems and Human Wellbeing (San Francisco: Island Press).

Ostrom, E. (1990) Governing the Commons. The Evolution of Institutions for Collective Action (Cambridge University Press).

Ostrom, E. (2005) Understanding Institutional Diversity (Princeton University Press).

Ostrom, E. (2007) 'A Diagnostic Approach for Going Beyond Panaceas', Proceedings of the National Academy of Sciences, 104(39):15181-15187.

Ostrom, E. (2009) A Polycentric Approach for Coping with Climate Change. Policy Working Paper 1 (Washington, DC: The World Bank). 
Ostrom, E., Dietz, T., Dolšak, N., Stern, P.C., Stonich, S. and Weber, E.U. (eds), (2001) Drama of the Commons (Washington, DC: National Academy of Science). Pierce-Colfer, C. (eds) (1997) Who Counts Most for Sustainable Forest Management? (CIFOR).

Ribot, J., Agrawal, A. and Larson, A. (2006) 'Recentralizing While Decentralizing: How National Governments Re-appropriate Forest Resources', World Development 34(11): 1864-1886.

Rockström, J., Will, S. and Noone, K. et al. (2009) 'Feature: A Safe Operating Space for Humanity', Nature 461: 472-475.

Schlager, E. and Ostrom, E. (1992) 'Property-Rights Regimes and Natural Resources: A Conceptual Analysis', Land Economics, 68(3): 249-262.

Warman, A. (2000) El Campo en México en el Siglo XX. Siglo de Luces y Sombras (México: Fondo de Cultura Económica). Cornleius, W. Ejido Reform: Stimulus or Alternative to Migration. The Transformation of Rural Mexico. Transforming the Ejido Sector (San Diego: Center for US-Mexico Studies).

Wollenberg, E., Merino, L., Agrawal, A. and Ostrom, E. (2007) 'Fourteen Years of Monitoring Community-Managed Forests: Learning from IFRI's Experience', International Forestry Review 9(2): 670-684.

Except where otherwise noted, this work is licensed under a Creative Commons Attribution 3.0 Unported License. To view a copy of this license, visit http://creativecommons.org/licenses/by/3.0/ 